\title{
Impact of UV-radiation on viability, photosynthetic characteristics and DNA of brown algal zoospores: implications for depth zonation
}

\author{
Christian Wiencke ${ }^{1, *}$, Iván Gómez ${ }^{1, * *}$, Hans Pakker $^{2}$, Antonio Flores-Moya ${ }^{3}$, \\ María Altamirano ${ }^{3}$, Dieter Hanelt ${ }^{1}$, Kai Bischof ${ }^{1}$, Félix L. Figueroa ${ }^{4}$ \\ ${ }^{1}$ Foundation Alfred Wegener Institute, Projectgroup: Solar UV-radiation, Columbusstrasse, 27515 Bremerhaven, Germany \\ ${ }^{2}$ Department of Marine Biology, University of Groningen, PO Box 14, 9750 AA Haren, The Netherlands \\ ${ }^{3}$ Department of Plant Biology, and ${ }^{4}$ Department of Ecology, University of Málaga, Campus de Teatinos $s / n$, \\ 29071 Málaga, Spain
}

\begin{abstract}
Measurements of photosynthesis, germination capacity and assessment of DNA damage were carried out in the laboratory to determine the effect of different conditions of ultraviolet (UV) and photosynthetically active radiation (PAR) on zoospores of various large brown algae collected on Spitsbergen (Svalbard, High Arctic) and Tarifa (Cádiz, southern Spain). Results were correlated to in situ light conditions and indicated that zoospores suffer photoinhibition of photosynthesis, loss of viability and DNA damage in relation to the growth depth of parental sporophytes. At both sites, germination capacity of zoospores in species collected in deep waters was more strongly impaired after exposure to the same UV doses than in species from shallower waters. In general, zoospores exposed to $\mathrm{PAR}+U V A+\mathrm{UVB}$ showed higher mortality rates than after exposure to PAR+UVA or PAR alone. For Laminaria digitata from Spitsbergen, it was found that the loss of zoospore viability is the result of DNA. damage and photodamage of the photosynthetic apparatus. UVB irradiances occurring in southern Spain at water depths shallower than $7 \mathrm{~m}$ prevented the germination of spores of deep water Laminariales from this region.
\end{abstract}

KEY WORDS: Macroalgae $\cdot$ Laminaria A Arctic - Zoospores - UV-radiation D DNA damage Photosynthesis

\section{INTRODUCTION}

Depth distribution patterns of large kelps (Laminariales) have been frequently thought to reflect the light requirements of their establishment stages (zoospores, germlings, etc.), which are strongly affected by both light quality and intensity (Lüning 1980). However, most of the studies designed to address the relationship between the light environment and macroalgal zonation have been focused on the large sporophytic stages (Lüning 1979, Lüning \& Dring 1979), whereas

\footnotetext{
-E-mail: cwiencke@awi-bremerhàven.de

- Present address: Foundation Alfred Wegener Institute, Section Coastal Ecology, Hafenstrasse 43, 25992 List/Sylt, Germany
}

physiological adaptations to depth of motile zoospores have been largely overlooked (Kain 1964, Lüning 1980, Amsler \& Neushul 1991). For example, some evidence indicates that photosynthetic rates of kelp zoospores are low, just balancing respiration (Kain 1964), and carbon assimilation of zoospores might condition their viability and dispersal capacity (Amsler \& Neushul 1991). Thus, it is reasonable to suppose that the ability of spore stages to acclimate to different light environments will have consequences for population dynamics (Reed 1990).

Since the detection of stratospheric ozone depletion, many efforts have been undertaken to evaluate the detrimental impact of enhanced UVB radiation on marine organisms (Holm-Hansen et al. 1993, Larkum \& Wood 1993, Wängberg et al. 1996). In macroalgae, an 
increasing number of photobiological studies (mostly using macrothalli) indicate diverse physiological alterations as a response to UV-radiation, including pigment degradation, dynamic or chronic photoinhibition of photosynthesis, and DNA damage (reviewed in Franklin \& Forster 1997, Häder \& Figueroa 1997). Interestingly, the degree of vulnerability to UV and visible radiation is a function of the vertical distribution of macroalgae from polar (Hanelt et al. 1997b, Hanelt 1998, Bischof et al. 1998a,b) and temperate regions (Larkum \& Wood 1993, Maegawa et al. 1993, Dring et al. 1996b, Häder et al. 1997, Sagert et al. 1997, Jiménez et al. 1998). However, the question of whether early developmental stages of macroalgae, particularly zoospores, are more susceptible to UV-radiation than large developmental stages has received little attention (Dring et al. 1996a, Yakovleva et al. 1998). This contrasts with the intensive research conducted on spores of microorganisms and fungi, which are currently used as biological dosimeters in monitoring of UV-dependent responses (Munakata 1995, Tyrrell 1995, Quintern et al. 1997). Taking into account that macroalgal spores are devoid of thick cell walls and are physiologically active, in contrast to the resistant or dormant character of fungal or cyanobacterial spores, an enhanced susceptibility to UVB radiation, e.g. DNA damage, may be expected. Moreover, their haploid state (Lee 1989) and the presence of only 1 chloroplast in the Laminariales (Henry \& Cole 1982) make zoospores a very interesting life-history stage for detection of deleterious effects of UV on the whole organism. Some results from microalgae, which may be extrapolated to the situation in planktonic zoospores of macroalgae, reveal that induction of cyclobutane pyrimidine dimers (thymine dimers) and other photoproducts as a result of DNA damage varies in relation to cell size, organelle arrangement or cell-aggregation. Such morphological characteristics affect the transmittance of light through the protoplasm and the amount of UVB quanta that reaches DNA molecules and other cellular targets (Karentz et al. 1991, Mitchell \& Karentz 1993).

In polar regions, algae are exposed to seasonally strongly changing light conditions. Recent studies indicate that UVB irradiances can penetrate down to water depths between 5 and $10 \mathrm{~m}$, depending on the season (Holm-Hansen et al. 1993, Bischof et al. 1998a). Under such conditions a clear relationship between depth and photoinhibition of photosynthesis in response to UV-radiation has been reported in sporophytes of Arctic Laminaria species (Hanelt et al. 1997a, Bischof et al. 1998a) and in a variety of macroalgal species from the Antarctic (Bischof et al. 1998b). However, the degree of vulnerability to UV-radiation exhibited by large sporophytes is unlikely to be the only factor determining depth zonation in these species, and other processes occurring at early stages may be involved. Therefore, the present study focuses on the impact of UV-radiation on germination capacity, photosynthetic efficiency (variable fluorescence of PSII) and DNA damage of zoospores of subtidal Laminariales from the Arctic. The hypothesis that susceptibility of zoospores to UV-radiation is an adaptive character that effectively limits recruitment in shallow waters is addressed. In order to put data into a geographical perspective, zoospore viability of 4 species of Laminariales from southern Spain was also included in the study. The idea that excess solar radiation may also be a major factor determining the upper depth distribution of Laminariales in this region has hitherto not been addressed. Thus, the comparison between zoospores of Arctic and temperate macroalgae after UV-exposure gives valuable new insights into the light-stress tolerance mechanisms related to recruitment of these important macroalgal assemblages in a scenario of enhanced UV-radiation.

\section{MATERIAL AND METHODS}

Sampling sites and algal material. Arctic: Laminaria saccharina, L. digitata, Alaria esculenta and Chordaria flagelliformis were collected by SCUBA diving between 1 and $5 \mathrm{~m}$ depth in Kongsfjorden, west coast of Spitsbergen, Svalbard ( $\mathrm{Ny} \AA$ lesund, $78^{\circ} 55^{\prime} \mathrm{N}$, $11^{\circ} 56^{\prime} \mathrm{E}$; Fig. 1a). This narrow and deep fjord (maximum depth: $400 \mathrm{~m}$ ) covers an area of $208 \mathrm{~km}^{2}$ with a maximum length of $26 \mathrm{~km}$ and a mean width of $8 \mathrm{~km}$. The coast line is characterized by abundant glaciers which strongly influence the physical environment of the fjord (see Ito \& Kudoh [1997] for details of hydrographical data). The shores are characterized by a rocky substrate, pebbles, stones (sandstone and limestone) with sporadic sandy bottoms. Macroalgae are primarily subtidal, with Fucus distichus and Pilayella littoralis being almost the only species occurring above the zero line in the intertidal zone (diurnal tidal regime, range ca $2 \mathrm{~m}$ ). The upper sublittoral zone ( $<4.5 \mathrm{~m}$ depth) is characterized by species such as Acrosiphonia flagelliformis and single individuals of $L$. digitata, A. esculenta and C. flagelliformis. A dense community with L. saccharina and Saccorhiza dermatodea as canopy species is well developed in an intermediate zone between 5 and $16 \mathrm{~m}$ depth. L. digitata and $A$. esculenta individuals also occur intermixed at these depths. Deep-water species such as Laminaria solidungula and some red algae Polysiphonia sp. and Phycodrys sp. extend below $17 \mathrm{~m}$. The persistence and composition of species described are strongly modified by ice cover (light attenuation) and abrasion by floating ice masses (see Svendsen 1959). 
Southern Spain: Specimens of Saccorhiza polyschides, Laminaria ochroleuca, Phyllariopsis brevipes and P. purpurascens were sampled by SCUBA diving at depths between 15 and $30 \mathrm{~m}$ in Tarifa, Cádiz, southern Spain (Isla de las Palomas, $36^{\circ} 00^{\prime} \mathrm{N}, 5^{\circ} 28^{\circ} \mathrm{W}$, Fig. 1b). This coast represents a transition between Atlantic and Mediterranean waters. The upper water mass (up to $150 \mathrm{~m}$ depth) is the Atlantic component, which is characterized by temperatures higher than $20^{\circ} \mathrm{C}$ and salinities lower than $36.5 \%$ in summer. Down to a depth of 100 to $150 \mathrm{~m}$ it is possible to distinguish the deep Mediterranean water layer, which is more dense and exhibits a lower temperature $\left(38.4 \%\right.$ and $\left.12.9^{\circ} \mathrm{C}\right)$ than the upper one. Thus, the photic zone and especially the littoral assemblages are basically subjected to Atlantic conditions (Rodríguez 1982). Between 10 and $20 \mathrm{~m}$ depth, temperature decreases by $4^{\circ} \mathrm{C}$ (Flores-Moya 1997). Tides are semidiurnal, and in Tarifa the maximum range does not exceed $2 \mathrm{~m}$ amplitude. In the upper littoral zone, algal assemblages are dominated by the sun-adapted species Fucus spixalis and Porphyra leucosticta (seasonal). The mid-littoral is dominated by various red algal species (Gelidium sp., Corallina sp., Asparagopsis sp, etc.) and the green alga Ulva sp. Below 5 to $10 \mathrm{~m}$ (upper limit of the Laminariales), brown algae of the genera Phyllari- opsis, Laminaria and Saccorhiza form conspicuous assemblages. P. purpurascens is particularly abundant at depths close to $30 \mathrm{~m}$. During late winter-spring, young sporophytes of some Laminariales commonly restricted to deep waters have been seen to colonise rocky crevices and other shaded habitats at upper sublittoral levels (4 m; Flores-Moya et al. 1993).

Measurements of in situ quantum irradiance. Measurements of underwater photosynthetically active radiation (PAR, 400 to $700 \mathrm{~nm}$ ) in Kongsfjorden were carried out using $2 \mathrm{Li}$-Cor cosine corrected irradiance sensors connected to a datalogger (Li-1000, Li-Cor Inc., Lincoln USA) during several days between May and August, 1997. Profiles of UVB (280 to $320 \mathrm{~nm}$ ) radiation were made by using a computer-controlled 32 channel single-quantum-counting radiometer developed at the Alfred Wegener Institute mounted in a watertight pressure housing (ISITEC, Bremerhaven, Germany). The instrument, designed to measure continuous and single fluence rates of UVB, was fixed to a pulley anchored at the bottom of the fjord, and profiling was done by drawing it from just below the surface to the specific depth. The instrumentation was calibrated against a $1000 \mathrm{~W}$ quartz halogen calibration lamp (Gigahertz Optik, Germany).

a)
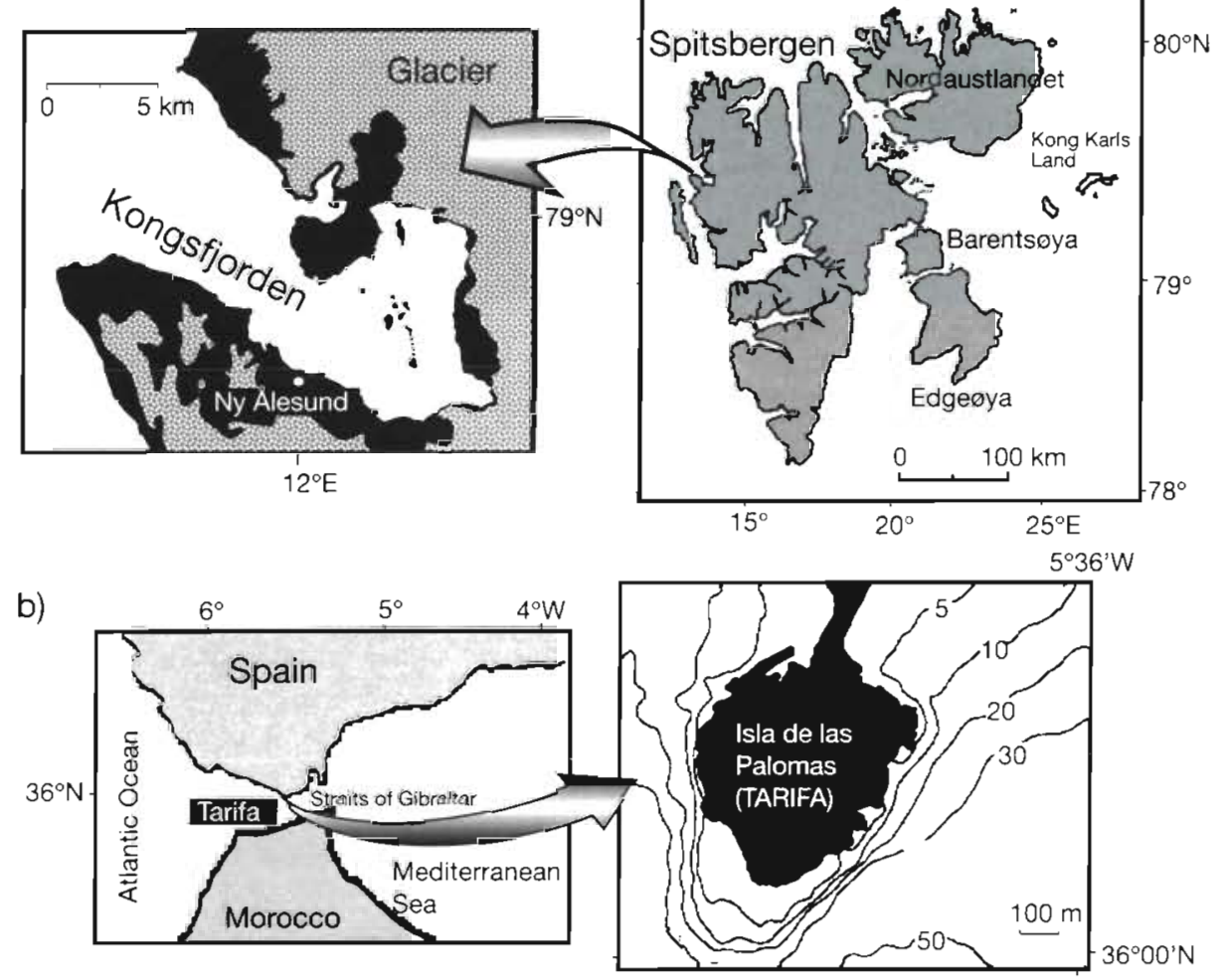

Fig. 1. Maps indicating the collecting sites at (a) Kongsfjorden (Spitsbergen) and (b) Tarifa (southern Spain) 
Water column profiles on the coast of Tarifa were performed using a computer controlled PUV-500 radiometer (Biospherical Instruments Inc., USA), which gives readings of cosine-corrected downwelling UV-radiation at 4 bands, 305, 320 (UVB), 340, and $380 \mathrm{~nm}$ (UVA) and a broad band of PAR (400 to $700 \mathrm{~nm}$ ). Measurements were made by slowly submerging the instrument through the water column to depths of $45 \mathrm{~m}$. Simultaneously, depth profiles of spectral irradiance in the range between 300 and $800 \mathrm{~nm}$, i.e. including also the UVA region, were made using a spectroradiometer (Li-Cor 1800-UW) at different intervals between 0 (just below of the surface) and $32 \mathrm{~m}$ depth. These light measurements were performed only on one day in October 1997. In general, the weather conditions and water transparency in this region of southern Spain are good between May and November, making marked variations in light attenuation patterns unlikely. It should be mentioned that the instrumentation used for measurements at both sites were intercalibrated in order to make data comparable.

Diffuse attenuation coefficients $\left(K_{\mathrm{d}}\right)$ were calculated by linear regression of natural logarithm (ln) transformed irradiance data versus depth:

$$
K_{\mathrm{d}}=\left[\ln \left(I_{0}\right)-\ln \left(I_{z}\right)\right] \times z^{-1}
$$

where $I_{0}$ is the irradiance just below the water surface, and $I_{z}$ the irradiance at depth $z$ (m). For the calculations of $K_{d}$ from the $305 \mathrm{~nm}$ channel, only data in the log-linear region of the curve were used. Percentage transmission $(T)$ was calculated as:

$$
T=\left[I_{0} \times 100\right] \times I_{z}^{-1}
$$

Thus, the point at which the slope of the log transformed data intercepts the depth axis was used to estimate the depth of the $1 \%$ of the level of $I_{0}$. In situ spectral irradiance data at each site were also used to calculate biologically weighted UVB doses (DNA damage, Setlow 1974) at different depths as described below.

Light environment and optical characteristics. Incident solar radiation measured at the surface was clearly lower in Kongsfjorden than in Tarifa (Table 1). In general, higher UV-radiation was recorded in the vertical profiles made in Tarifa, whereas $K_{\mathrm{d}}$ was significantly higher in the area of Kongsfjorden than in Tarifa. Consequently, the $1 \% I_{0}$ depth estimated for Tarifa varied between $16.4 \mathrm{~m}$ for the $305 \mathrm{~nm}$ (UVB) band and $43.3 \mathrm{~m}$ for photosynthetically active radiation (PAR). In contrast, the $1 \% I_{0}$ depth of PAR in the Kongsfjorden was about $7 \mathrm{~m}$. An estimation of the lower limit of light penetration $\left(D_{0.1}\right)$ using broad wavelength bands indicated that $0.1 \% I_{0}$ of PAR and UV (UVA and UVB) can reach great depths (between 25 and $67 \mathrm{~m}$ ) under sunny conditions in southern Spain, whereas UV and visible radiation in Kongsfjorden are restricted to depths $<20 \mathrm{~m}$. It must be emphasized that the optical characteristics described for Kongsfjorden correspond to an ice-free season. Under overlying ice-cover during late winter-early spring, light conditions are greatly reduced. (See Bischof et al. [1998] for additional details on bio-optical characteristics of the waters in Kongsfjorden.)

Experimental design and light source. To evaluate the effects of exposure to UV-radiation on the mortality rate of zoospores and their photosynthetic responses, the samples were irradiated using 2 different lamps: PAR - Duro-Test, Truelite II, USA; UVA + UVB (UVA340, Q-Panel, USA). Each of the Petri dishes were covered with different cut off filters to obtain a combination of 3 radiation treatments: (1) PAR + UVA + UVB, by use of Schott-WG 280 (Schott, Germany) or Ultraphan 295 (Digefra GmbH, Germany). (2) PAR + UVA, by use of Schott-WG 320 or Folex 320 (Folex GmbH, Germany). (3) PAR alone, by use of Schott-GG 400 or Utraphan 395.

The spectral irradiances between 290 and $700 \mathrm{~nm}$ under the light sources and filters used for experiments with Arctic and southern Spain species were measured using a Spectro 320-D (Instrument Systems, Germany) and a Li-1800 spectroradiometer (Li-Cor Inc.), respectively. As an example, the spectral characteristics of the Schott-filter system are shown in Fig. 2. The irradiance conditions using Ultraphan and Folex foils were comparable and have previously been described (Figueroa et al. 1997b). In order to estimate the wavelength-dependent effectiveness of the UV-irradiances

Table 1. Optical characteristics of the collecting sites at Kongsfjorden (Spitsbergen) and Tarifa (southern Spain). Details of profiling, data acquisition and calculations are given in the 'Material and methods'. $I_{0}$, surface irradiance; $D_{1}$, depth at which irradiances reach $1 \%$ of $I_{0}$

\begin{tabular}{lccc|}
\hline Site/measurement & Maximum $I_{0}$ & $K_{\mathrm{d}}\left(\mathrm{m}^{-1}\right)$ & $D_{1}(\mathrm{~m})$ \\
\hline Kongsfjorden & & & \\
PAR $\left(400-700 \mathrm{~nm}^{-}\right)$ & 700 & 0.624 & 7.3 \\
$\left(\mu \mathrm{mol}\right.$ photons $\left.\mathrm{s}^{-1}\right)$ & & & \\
$\mathrm{UVB}$ bands $\left(\mathrm{W} \mathrm{m}^{-2} \mathrm{~nm}^{-1}\right)$ & & & \\
$305 \mathrm{~nm}$ & 0.0084 & 0.898 & 4.5 \\
$320 \mathrm{~nm}$ & 0.085 & 0.730 & 5.1 \\
Tarifa & & & \\
PAR $\left(400-700 \mathrm{~nm}^{-2}\right.$ & 1530 & 0.095 & 43.3 \\
$\left(\mu \mathrm{mol}\right.$ photons $\left.\mathrm{m}^{-1}\right)$ & & & \\
UVB bands $\left(\mathrm{W} \mathrm{m}^{-2} \mathrm{~nm}^{-1}\right)$ & & & \\
$305 \mathrm{~nm}$ & 0.0049 & 0.265 & 16.4 \\
$320 \mathrm{~nm}$ & 0.102 & 0.259 & 18.3 \\
UVA bands $\left(\mathrm{W} \mathrm{m}^{-2} \mathrm{~nm}^{-1}\right)$ & & & \\
$340 \mathrm{~nm}$ & 0.241 & 0.209 & 22.7 \\
$380 \mathrm{~nm}$ & 0.488 & 0.134 & 38.1 \\
\hline
\end{tabular}




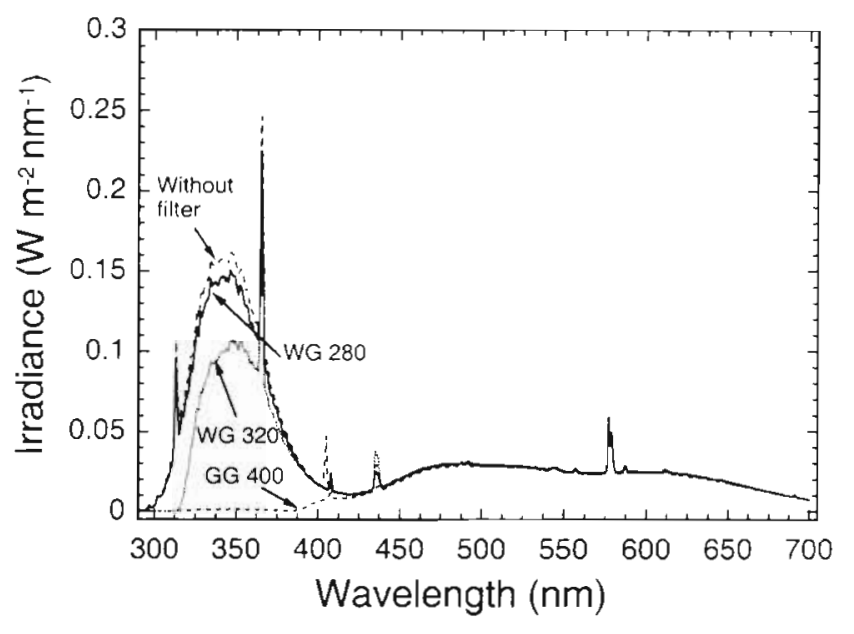

Fig. 2. Spectral irradiance of the UV-range (290 to $400 \mathrm{~nm}$ ) and PAR (400 to $700 \mathrm{~nm}$ ) emitted by the lamps and the effect of the cut-off filters (Schott) used in the experiments. WG $280=$ PAR+UVA+UVB $i$ WG $320=P^{P A R}+U_{V A}$ GG $400=$ PAR alone

applied in each treatment (biologically effective dose, $B E D)$, spectral irradiances in the range between 290 and $400 \mathrm{~nm}$ were weighted using 2 action spectra for well-known biological responses: DNA damage for $E$. coli (Setlow 1974) and the generalized plant damage described by Caldwell (1971). The weighted irradiance dose was then calculated by multiplying the incident spectral irradiance and the function described above (Rundel 1983):

$$
\mathrm{BED}=\int_{290}^{400} I_{\lambda} \cdot e_{\lambda} \alpha_{\lambda}
$$

where $I_{\lambda}$ is the irradiance at $\lambda \mathrm{nm}$ and $e_{\lambda}$ is the biological response at $\lambda \mathrm{nm}$ defined by the weighting function. Both unweighted and weighted irradiances for each treatment are compiled in Table 2. Undoubtedly, the UV/PAR ratios reached by our lamp systems did not match ratios normally measured under natural condi- tions, which has been discussed in previous reports (Dring et al. 1996a, Nilawati et al. 1997, Pérez-Rodríguez et al. 1998). A low PAR background, however, avoids possible masking of UV effects by excessive PAR (Molina \& Montecino 1996, Nilawati et al. 1997). Moreover, the low level of PAR used was not regarded to be a limiting factor for physiological requirements as studied macroalgae from both Arctic and southern Spain sites are shade-adapted species (Flores-Moya et al. 1993 Bischof et al. 1998b, Hanelt 1998; see 'Discussion').

Determination of spore mortality. Sporophytes of the different Arctic species containing abundant sori were collected during May-June 1997 and 1998. After sampling, fertile tissue was blotted with tissue paper and maintained for $2 \mathrm{~d}$ in a wet chamber at $0^{\circ} \mathrm{C}$, whereas the algae from south Spain were incubated at $15^{\circ} \mathrm{C}$. The number of specimens with sori in the south Spain area increased from June onwards with the largest percentage of fertile sporophytes occurring in October-November (see also Flores-Moya et al. 1993). To induce the release of zoospores, fertile sections of thalli were immersed in Provasoli enriched seawater (PES) in light $\left(14^{\circ} \mathrm{C}\right.$ for experiments with Arctic species and $15^{\circ} \mathrm{C}$ for specimens from southern Spain). The initial zoospore densities $\left(5 \times 10^{4}\right.$ to $\left.3 \times 10^{6} \mathrm{ml}^{-1}\right)$ for each species were then calculated using a Thoma chamber (Brand, Germany). From these suspensions, a few drops were taken and transferred to Petri dishes (diameter: $10 \mathrm{~cm}$, $\mathrm{n}=3$ ) containing PES medium (Starr \& Zeikus 1987). The zoospores were exposed to the radiation conditions described in Table 2. After 1, 2, 4, 8 and 16 h exposure, the Petri dishes were put under dim light ( $10 \mu \mathrm{mol}$ photon $\mathrm{m}^{-2} \mathrm{~s}^{-1}$ white light; 14 to $18 \mathrm{~h}$ light $\mathrm{d}^{-1}$ ) and cultivated there for $5 \mathrm{~d}$. Zoospore mortality was calculated from the scores of both dead and germinated zoospores (between 300 and 1500 single spores) for each treatment using a light microscope (Zeiss Axioplan, Germany) equipped with a $25 \times$ seawater immersion objective. Germinating zoospores were easily recognizable

Table 2. Lamp design indicating the experimental irradiances applied in each treatment (PAR/UVA UVB ratios $=0.8 / 1.0 / 0.1)$ and the corresponding weighted irradiances calculated using the biologically-effective weighting function for the DNA damage of E. coli (Setlow 1974) and general plant damage (Caldwell 1971)

\begin{tabular}{|lccccc|}
\hline Treatment & \multicolumn{2}{c}{$\begin{array}{c}\text { Experimental irradiance }\left(\mathrm{W} \mathrm{m}^{-2}\right) \\
\text { PAR }\end{array}$} & $\begin{array}{c}\text { UVA } \\
(400-700 \mathrm{~nm})\end{array}$ & $\begin{array}{c}\text { UVB } \\
(320-400 \mathrm{~nm})\end{array}$ & $\begin{array}{c}\text { Weighted irradiance }\left(\mathrm{W} \mathrm{m}^{-2}\right) \\
\text { DNA damage } \\
\text { Generalized plant damage } \\
\text { (Caldwell 197 })\end{array}$ \\
\hline $\begin{array}{l}\text { Without filter } \\
\text { WG 280 }\end{array}$ & 6.541 & 8.225 & 0.851 & 0.632 \\
$\begin{array}{l}\text { (PAR+UVA+UVB) } \\
\text { WG 320 }\end{array}$ & 6.535 & 7.599 & 0.567 & 0.077 & 0.554 \\
$\begin{array}{l}\text { (PAR+UVA) } \\
\text { GG 400 }\end{array}$ & 6.779 & 5.562 & 0.070 & 0.065 & 0.040 \\
(PAR alone) & 6.186 & 0.120 & 0.012 & 0.013 & 0.019 \\
\hline
\end{tabular}


by the formation of germ tubes and later of embryospores. Since even under white light some fraction of zoospores did not survive (due to imperfect maturity). an average number under PAR alone (GG 400 filter) was used as a control value to set the $100 \%$ living germlings. Finally, the percentage of dead cells was calculated using the following equation:

$$
\text { Dead zoospores }(\%)=100 \times\left(S_{\text {dead }}-D_{c}\right) \times L_{c}{ }^{-1}
$$

where $S_{\text {dead }}$ is the number of dead zoospores under UV-exposure, $D_{\mathrm{c}}$ and $L_{\mathrm{c}}$ are the \% of dead and living zoospores under white light, respectively.

Evaluation of DNA damage. In parallel with mortality experiments, spore suspensions of species collected in Kongsfjorden were taken at the same times for determination of DNA damage. The samples were filtered through a $2 \mu \mathrm{m}$ mesh polycarbonate filter and dried on activated silica gel. After 2 to $6 \mathrm{~h}$ the filters were transferred into a plastic tube covered with gauze, put into a plastic bag filled with activated silica gel and stored at $4^{\circ} \mathrm{C}$ in the dark until later analysis.

DNA extraction and analysis of DNA damage (formation of thymine dimers) was determined as follows: Each silica gel-dried filter was divided into 2 parts and from each half DNA was extracted independently using a CTAB (hexadecyltrimethylammonium bromide) extraction buffer. DNA was quantified fluorometrically with the PicoGreen dsDNA quantitation assay (Molecular Probes). The procedure for the quantification of thymine dimers was modified after Vink et al. (1994). Heat denaturated DNA samples $(0.2 \mu \mathrm{g})$ were transferred to a nitrocellulose filter (Protran $0.1 \mu \mathrm{m}$, Schleicher and Schuell, Germany) using a slotblot apparatus, and the filter was dried for $2 \mathrm{~h}$ at $80^{\circ} \mathrm{C}$ to immobilize DNA. To block specific sites, the filter was incubated in PBS-T (PBS $+0.1 \%[\mathrm{v} / \mathrm{v}]$ Tween-20, Sigma) with $5 \%(w / v)$ skim milk powder. Subsequently, the filter was washed in PBS-T (3x) and incubated with the first antibody, the thymine dimer-specific H3 (Roza et al. 1988). After washing ( $3 \times$ ), the filter was incubated with the second antibody (rabbit antimouse horseradish peroxidase). After washing $(4 \times)$, the filter was transferred to a buffer containing detection reagents (ECL, Amersham) which emit light during breakdown by the horseradish peroxidase. The filter was sealed in a transparent folder (Photogene development folder, GibcoBRL) and exposed to a photosensitive sheet (Hyperfilm ECL, Amersham). After the sheet was developed and fixed, it was scanned and the gray-scale values were quantified with the software program Image Quant (Molecular Dynamics). The number of thymine dimers per $10^{6}$ nucleotides was finally calculated by comparing the grey scale values of the samples with those from a dilution series of standard DNA with a known amount of thymine dimers.
Chlorophyll fluorescence. In Laminaria digitata, photosynthetic efficiency, measured as variable fluorescence of photosystem II (PSII), of zoospores and 2 to 3 mo old sporophytes were determined in vivo using a portable pulse amplitude modulation fluorometer (PAM 2000, Walz, Germany) after Schreiber et al.

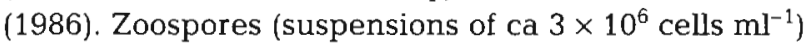
and sporophytes $(2 \mathrm{~cm}$ diameter disc samples from the basal part of the blade) were incubated for $3 \mathrm{~h}$ in Petri dishes (10 cm diameter) under the same light conditions used for determinations of zoospore mortality (Table 2). During the exposure period, algal material received doses of UVA and UVB close to 75.2 and $5.5 \mathrm{~kJ} \mathrm{~m}^{-2}$, respectively, with a PAR background of $61.24 \mathrm{~kJ} \mathrm{~m}^{-2}$. The optimum quantum yield $\left(F_{\mathrm{v}} / F_{\mathrm{m}}\right)$, i.e. the ratio of variable to maximum fluorescence, was measured after acclimatization in the dark for $10 \mathrm{~min}$ in a thermostatically controlled chamber. The parameter $F_{\mathrm{v}}$ defines the difference between the maximum fluorescence $F_{\mathrm{m}}$, when all reaction centers of PSII are reduced or 'closed' due to the saturation light pulse, and the initial fluorescence, $F_{0}$, i.e. when all PSII reaction centres are oxidized ('open'). Moreover, the time span of dark acclimatization used was optimal in different species of macroalgae. (See Hanelt et al. [1997b] and Hanelt [1998] for details of PAM 2000 fluorescence determinations of Arctic species.)

Data analysis. Effects of irradiation treatments on the physiological responses determined for different species, as well as for the developmental phases (zoospores and large sporophytes), were estimated by 2-way ANOVA (model I). In the case of ratios and percentages, data sets were firstly arcsine transformed. Multiple comparisons of means were carried out using the a posteriori Fisher test (Least Significance Difference, LSD) at p < 0.05 (Sokal \& Rohlf 1995).

\section{RESULTS}

\section{Mortality rates}

The various UV-treatments had a differential effect on the germination capacity of zoospores from the Arctic species (Fig. 3a). In Alaria esculenta and Chordaria flagelliformis, mortalities were about $60 \%$ after $16 \mathrm{~h}$ exposure to PAR+UVA+UVB, whereas zoospores irradiated with PAR+UVA showed a low mortality (20\%) after the same period. Laminaria digitata and L. Saccharina zoospore viability was very strongly affected by exposures to PAR+UVA+UVB. During the first hours of exposure, PAR+UVA+UVB was more effective in causing spore mortality than radiation deprived of UVB. This situation was not observed in L. digitata, where a differential response to the treatments was 


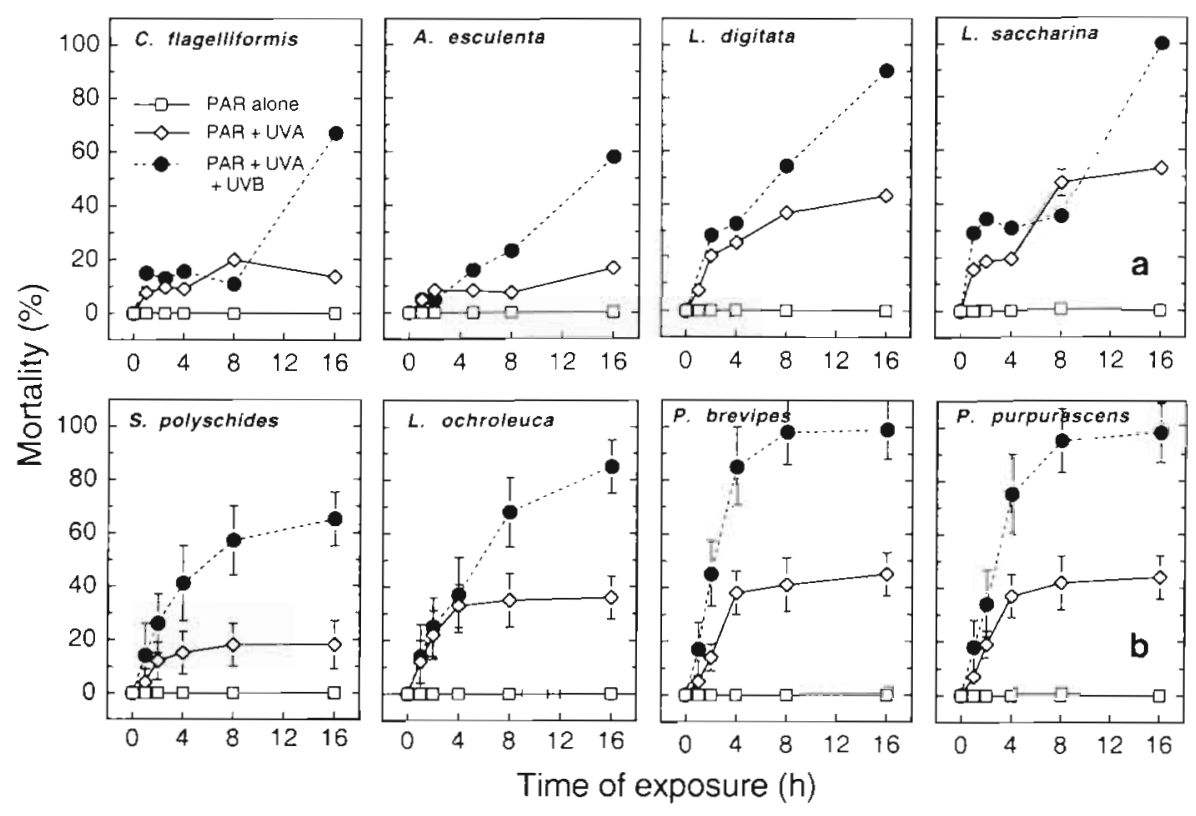

Fig. 3. Mortality of zoospores from macroalgae collected in (a) Kongsfjorden and (b) Tarifa after exposure to different conditions of PAR and UV-radiation using cut-off filters. Data are means \pm SD of 3 samples. See 'Results' for details

seen only after $8 \mathrm{~h}$ exposure. Likewise, the UVB affected zoospore viability more than UVA alone in species from southern Spain; however, the numbers of viable zoospores declined more strongly during the first 4 h of exposure to PAR+UVA+UVB (Fig. 3B) compared to the Arctic species. This was particularly evident in both Phyllariopsis species, whereas Sacchoriza polyschides showed the highest tolerance.

The dose-response data (Table 3) using weighted irradiances (DNA damage and generalized plant damage) indicate a correlation between viability of zoospores and growth depth of sporophytes. In shallow-water species, Chordaria flagelliformis and Alaria esculenta from Spitsbergen, biologically effective UVB doses above 2.8 and $23 \mathrm{~kJ} \mathrm{~m}^{-2}$ (DNA damage and plant damage action spectra, respectively) would be required to cause $50 \%$ of spore mortality. In contrast, $50 \%$ of spore mortality was already observed at doses of $1 \mathrm{~kJ} \mathrm{~m}^{-2}$ (DNA damage) or $13 \mathrm{~kJ} \mathrm{~m}^{-2}$ (generalized plant damage) in mid-sublittoral species such as Laminaria saccharina and in species from south Spain (Phyllariopsis sp.).

\section{DNA damage}

Zoospores of the Arctic species Alaria esculenta, Laminaria saccharina and L. digitata show a different degree of DNA damage (Fig. 4): in $L$. saccharina and $L$. digitata, 2 species from the mid-sublittoral, thymine dimer formation in plants irradiated with PAR+UVA+UVB (WG 280) for $4 \mathrm{~h}$ $\left(0.94 \mathrm{~kJ} \mathrm{~m}^{-2} \mathrm{BED}_{\mathrm{DNA}-300}\right)$ varied between 100 and 150 thymine dimers (relative units). These values were correlated to a fraction of dead zoospores higher than $25 \%$. Conversely, in the shallow water species Alaria esculenta, formation of thymine dimers after exposure to UV-radiation (WG 280) was negligible $(<3$ dimers per $10^{6}$ nucleotides) and comparable to values measured in Laminaria after exposure to only PAR (GG 400 ) for $4 \mathrm{~h}$. Results from dose-response experiments

Table 3. Estimated biologically effective UV dose (BED) (DNA damage and generalized plant damage) causing $50 \%$ spore mortality in each species. Values were calculated by regression analysis of the dose-response data using weighted irradiances. See 'Results' section for details of BEDs calculations

\begin{tabular}{|lcc|}
\hline Species & \multicolumn{2}{c}{ BED $\left(\mathrm{kJ} \mathrm{m}^{-2}\right)$} \\
& $\begin{array}{c}\text { DNA damage } \\
\text { (Setlow 1974) }\end{array}$ & $\begin{array}{c}\text { Geralized plant } \\
\text { damage } \\
\text { (Caldwell 1971) }\end{array}$ \\
\hline Kongsfjorden & & \\
Chordaria flagelliformis & 2.8 & 23.5 \\
Alaria esculenta & 3.4 & 25.2 \\
Laminaria digitata & 1.2 & 7.16 \\
Laminaria saccharina & 0.6 & 6.6 \\
Tarifa & & \\
Saccorhiza polyschides & 1.56 & 13.4 \\
Laminaria ochroleuca & 1.05 & 8.9 \\
Phyllariopsis brevipes & 0.46 & 3.9 \\
Phyllariopsis purpurascens & 0.54 & 4.5 \\
& & \\
\hline
\end{tabular}




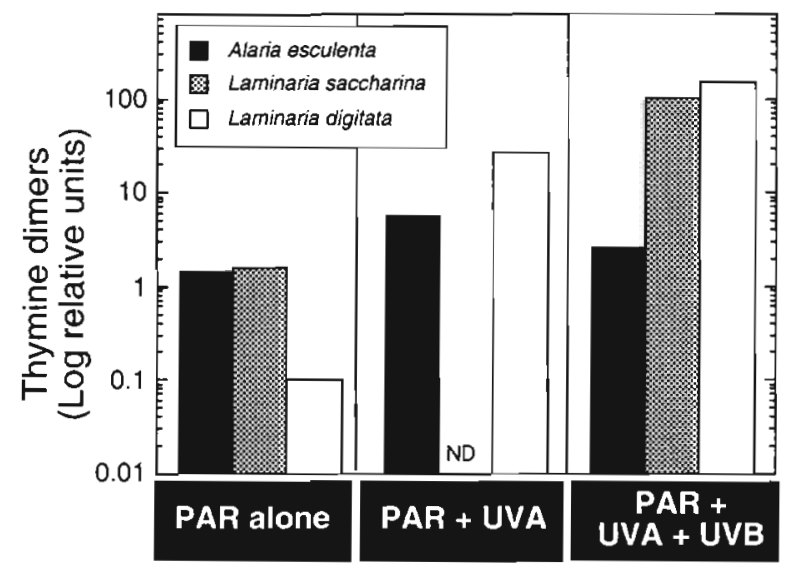

Fig. 4. DNA damage measured as formation of thymine dimers in zoospores of 3 brown algal species from the Kongsfjorden after exposure for $4 \mathrm{~h}$ to different conditions of PAR and UV-radiation. ND: not determined. Details are given in the 'Results'

carried out in L. digitata show that formation of thymine dimers increased linearly as a function of the increasing UVB dose (BED ${ }_{D N A-300 ;}$ Fig. 5). Plants exposed to doses above $0.4 \mathrm{~kJ} \mathrm{~m}^{-2}$ had between 35 and 70 thymine dimers per $10^{6}$ nucleotides whereas doses below $0.3 \mathrm{~kJ} \mathrm{~m}^{-2}$ were not effective in causing DNA damage.

\section{PAM chlorophyll fluorescence}

Fig. 6 shows the changes in $F_{\mathrm{v}} / F_{\mathrm{m}}$ of zoospores and large sporophytes of Laminaria digitata after exposure to a combination of UV conditions using different cut-

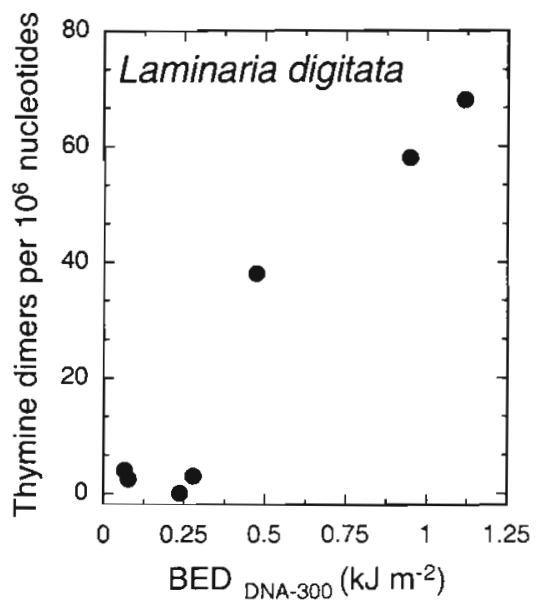

Fig. 5. Relationship between the DNA damage measured as thymine dimer formation in Laminaria digitata and the biologically effective dose (BED) of irradiances weighted using the action spectra for DNA damage described by Setlow (1974)

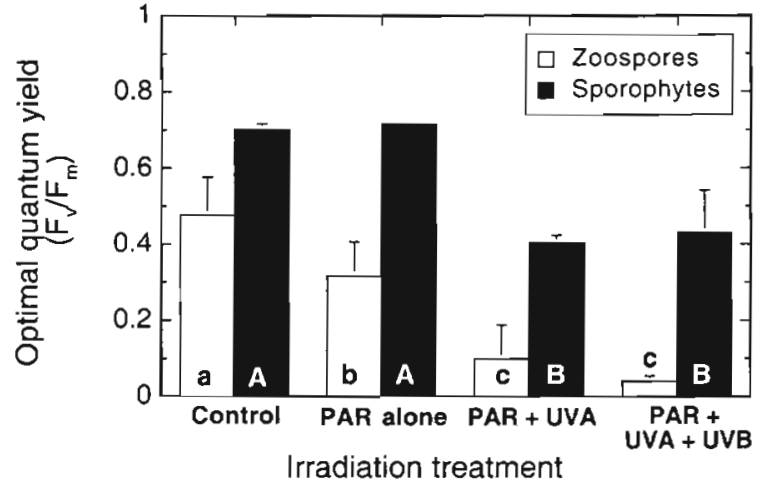

Fig. 6. Effects of different conditions of PAR and UV-radiation on chlorophyll fluorescence (optimal quantum yield, $F_{\mathrm{v}} / F_{\mathrm{m}}$ ) of zoospores and sporophytes of Laminaria digitata. Algal material was irradiated for $2.5 \mathrm{~h}$ with the spectra shown in Fig. 2. Data are means \pm SD (6 to 8 samples\}. Similar letters denote no significant differences ( $p>0.05$ ) among means after an ANOVA and Fisher LSD test. Control represents fluorescence in plants measured immediately after sampling

off filters. Both the different developmental stages and the UV treatments significantly affected the variations in $F_{\mathrm{v}} / F_{\mathrm{m}}$ (p $<0.01 ; 2$-way ANOVA). Irrespective of the UV treatment, large sporophytes showed the highest $F_{\mathrm{v}} / F_{\mathrm{m}}$ values compared to zoospores $(\mathrm{p}<0.05)$. In general, exposure to PAR+UVA and PAR+UVA+UVB exerted a similar photoinhibitory effect, which was especially marked on the zoospores $(p<0.05)$. In large sporophytes, exposure to UV-radiation for 2.5 h caused a significant reduction in the fluorescence ratio of up to $60 \%$ of controls deprived of any UV-radiation.

\section{DISCUSSION}

\section{Effects of UV-radiation on spore viability}

Spore mortalities measured after $16 \mathrm{~h}$ of exposure to $P A R+U V A+U V B$ and PAR+UVA indicate a relationship between the position of the adult plant on the shore and the UV-tolerance capacity of their zoospores. Additionally, the effect of exposure to PAR+UVA+UVB on the zoospore viability relative to that caused by PAR+UVA is higher in species from the shallow sublittoral, such as Chordaria flagelliformis and Alaria esculenta.

Dring et al. (1996b) reported that a loss of germination capacity of Laminaria saccharina, L. hyperborea and L. digitata from Helgoland (North Sea) became evident after $1 \mathrm{~h}$ exposure to levels of artificial irradiation comparable to that used in our study. After $12 \mathrm{~h}$, germination capacity decreased to less than $30 \%$ in the 3 species. In the case of Laminariales from the Arctic and southern Spain, a noticeable reduction in spore 
viability was observed after $4 \mathrm{~h}$ exposure to UV. This was particularly marked in the deep-water species Phyllariopsis purpurascens and $P$. brevipes, in which 50 and $90 \%$ loss of viability was observed after 2 and $4 \mathrm{~h} \mathrm{UV}$, respectively. In terms of weighted UV doses, $50 \%$ of spore mortality in L. digitata and L. saccharina from Spitsbergen and $L$. ochroleuca, $P$. brevipes and $P$. purpurascens from southern Spain would occur at doses $=1 \mathrm{~kJ} \mathrm{~m}^{-2} \mathrm{BED}_{\text {DNA-300 }}$ or $10 \mathrm{~kJ} \mathrm{~m}^{-2} \mathrm{BED}_{\text {plant damage }}$. However, it must be emphasized that in our study reciprocity, i.e. the effect of dose regardless of irradiance rates (cf. Smith et al. 1980), was not tested and care must be taken when data are used to predict possible consequences for zonation (see below). For example, $50 \%$ of tetraspores of the littoral red alga Ceramium rubrum from the North Sea survived after exposures at $2.2 \mathrm{~W} \mathrm{~m}^{-2}$ UVB and $11 \mathrm{~W} \mathrm{~m} \mathrm{~m}^{-2}$ UVA for $1 \mathrm{~h}_{i}$ however, when these doses were increased by 3 or 4 times, survival decreased to $7 \%$ (Yakovleva et al. 1998). In any case, the absence of reciprocity does not necessarily preclude the wavelength-dependent effect of UVB on the biological response, and time scale of exposure should always be indicated in this type of study (Cullen \& Lesser 1991). Conversely, mortality after $4 \mathrm{~h}$ PAR+UVA irradiation reaches a saturation level in all species, indicating that zoospores do not possess identical UV-tolerance capacity. Instead, they constitute a heterogeneous population formed by UV-sensitive and non-sensitive cells, explaining the survival of more than $50 \%$ of zoospores after $16 \mathrm{~h}$.

The loss of viability, expressed as cellular disintegration or loss of germination capacity (Dring et al. 1996a), is the result of the deleterious effect of UV-radiation on the zoospore. However, which cellular structures or processes are primarily affected by UVB? In the case of biflagellate brown algal zoospores, motility or phototaxis may be impaired first by UV, as in the flagellate Euglena gracilis (Häder \& Häder 1988, Ekelund 1996). In general, zoospores of Laminariales remain motile for about 20 h after release from sporangia (Kain 1964, Makarov 1992). During this period, naked zoospores are directly exposed to the prevailing light conditions in the water column, as other components of the phytoplankton. Nanoplankton-sized flagellates ( 2 to $20 \mu \mathrm{m}$ ) are the phytoplankton group most sensitive to UV (Häder \& Häder 1989, Helbling et al. 1994, Figueroa et al. 1997a). Small zoospores exhibit only few constitutive (structural or physiological) mechanisms of photoprotection and their acclimation potential to light stress is very limited (Amsler \& Neushul 1991). Mortalities of Antarctic biflagellate stages of Phaeocystis sp. (5 to $8 \mu \mathrm{m} \varnothing)$ are close to $95 \%$, after exposure to $0.58 \mathrm{~J} \mathrm{~m}^{-2}$ UVB in the laboratory, a value significantly higher than determined in various species of diatoms (Davidson \& Marchant 1994). Therefore, it is reasonable to argue that macroalgae are most vulnerable to UV-radiation during this planktonic life history phase, especially if vertical mixing transports cells to shallower water (Cullen \& Lesser 1991, Helbling et al. 1994).

\section{DNA damage}

In contrast to the relatively abundant information on UVB-dependent DNA damage in higher plants (Beggs et al. 1986, Quaite et al. 1992) and phytoplankton (Small \& Greimann 1977, Karentz et al, 1991, Mitchell \& Karentz 1993, Gieskes \& Buma 1997), the effect of short wavelengths on the genetic material of macroalgae has up to now been practically ignored. Our results indicate that there is a direct relationship between DNA damage and mortality of zoospores of Arctic Laminaria species. In zoospores from algae growing at shallow sites (e.g. Alaria esculenta) thymine dimer formation was very low relative to that measured in zoospores from algae growing in deeper waters (e.g. L. digitata). As DNA does not absorb in the UVA region, some PAR+UVA mediated DNA damage ( $=3$ thymine dimers per $10^{6}$ nucleotides) could be caused by indirect action of oxygen radicals (Bornman \& Teramura 1993). It is unknown if repair mechanisms (e.g. photoreactivation) are active in zoospores. As mentioned for the photosynthetic apparatus, cell size appears to be a critical factor determining the extent to which UVB quanta reach DNA molecules (Karentz et al. 1991, Mitchell \& Karentz 1993). Although we do not have data on DNA damage of sporophytes, it may be reasonable to argue that DNA of zoospores may be more sensitive to UVB than the multicellular developmental stages. For $L$. digitata zoospores, which are shade-adapted and are commonly subjected to very low light conditions, biologically effective UVB doses close to $1 \mathrm{~kJ} \mathrm{~m}^{-2}$ induce the formation of 60 to 70 thymine dimers per $10^{6}$ nucleotides, values in the range measured in the diatom Cyclotella sp. exposed to weighted doses $\left(B E D_{D N A-300}\right)$ up to $6 \mathrm{~kJ} \mathrm{~m}^{-2}$ (Buma et al. 1995). Undoubtedly, the occurrence of DNA damage in zoospores of Laminariales leads to many important questions referring to the survival and selective adaptation in benthic macroalgae: direct mutagenic and other sublethal alterations in the genomic information at this early developmental stage may have important consequences for the later development of sporophytes and gametophytes. For example, growth rates of L. religiosa gametophytes from Sapporo, Japan, are inhibited by $90 \%$ if parental zoospores have been irradiated at a UVB dose of $3 \mathrm{~kJ} \mathrm{~m}^{-2}$ (Yabe et al. 1997). It remains open as to whether a relationship between susceptibility to DNA damage and depth distribution of parental sporophytes is a common characteristic in kelps and whether such a relation also occurs at the level of large sporophytes. 


\section{Photosynthetic characteristics: shade adaptation of zoospores}

Measurements of chlorophyll fluorescence in Laminaria digitata from Spitsbergen show that zoospores are capable to photosynthesize at low rates. Conversely, irrespective of the light treatment, photosynthetic efficiency $\left(F_{\mathrm{v}} / F_{\mathrm{m}}\right)$ declined more strongly in zoospores than in large sporophytes. These findings are not surprising and support an adaptation to low light conditions documented in the literature (Kain 1964, Amsler \& Neushul 1991). Data from Macrocystis pyrifera, Nereocystis lutkeana and Pterygophora californica have revealed that zoospores can photosynthesize actively and supply part of their carbon requirements for metabolism (Ansler \& Neushul 1991). The lower $F_{\mathrm{v}} / F_{\mathrm{m}}$ values measured in zoospores relative to sporophytes in $L$. digitata is interrelated to a lower chlorophyll content, corresponding to the presence of only 1 chloroplast in the zoospores of Laminariales (Henry \& Cole 1982). This would support the idea that the photosynthetic machinery at this level is not completely developed or, as has been suggested by Amsler \& Neushul (1991), a fraction of the pigment-protein complexes is stored as nitrogen reserves for use during germination of gametophytes. In terms of energy allocation, this low photosynthetic efficiency may be sufficient to support respiratory demands during the planktonic phase. As has been demonstrated in the flagellate euglenophyte Euglena gracilis, decreases in photosynthesis after UV-exposure are not necessarily coupled to any reduction in flagellar activity (Häder \& Häder 1989, Ekelund 1996), and thus, it maybe that motility of zoospores is mainly supported by degradation of reserve compounds. Effects on other related settlement processes of such as chemotaxis and phototaxis targeted by high light stress (PAR or UV-radiation) also require investigation.

Zoospore shade adaptation is primarily conferred by the structural and optical characteristics of the cell (Garcia-Pichel 1996) with 2 contrasting consequences for photobiology. On the one hand, thin cell walls and a transparent cellular cytoplasm allow a very efficient light transmission towards the light harvesting complexes. Therefore under low photon fluence rates, absorption of PAR can be enhanced per chlorophyll unit (Enríquez et al. 1994). On the other hand, scattering and heterogeneous diffusion of light throughout the different cellular layers in a multicellular thallus (self-shading), can considerably ameliorate deleterious effects of UV-radiation (Halldal 1964). In this sense, the commonly described aggregation of zoospores after release in these species (Charter et al. 1973, Makarov 1992, author's pers. obs.) may be advantageous in avoiding photodamage of cells by high light stress, as has been demonstrated in Antarctic Phaeocystis sp. Under similar conditions of UVB, survival of colonial stages of this species were less affected than singleflagellate stages (Davidson \& Marchant 1994). As zoospores and early developmental stages of macroalgae exhibit lower light requirements for compensation and saturation of photosynthesis than large sporophytes (Kain 1964, Amsler \& Neushul 1991, Gómez \& Wiencke 1996), a short planktonic phase and a rapid settling of zoospores in areas under the canopy shadow of parental plants may also reduce the impact of harmful wavelengths (Graham 1996).

\section{Ecological implications: depth zonation}

In terms of UV-tolerance, dispersal and survival capacity, zoospores may be regarded as a critical life stage, determining the upper distribution limit of kelps. Regarding our results, possible scenarios may be outlined for the 2 sites in Kongsfjorden and Tarifa (Fig. 7). In Kongsfjorden, characterized by turbid water and additionally by presence of ice-cover until early summer, kelps may be able to grow at shallow sites (1.5 to $2 \mathrm{~m}$ depth), i.e., well beneath the ice-cover in winter. Weighted UVB doses using the DNA-damage action spectrum (Setlow 1974) estimated for depths between 0 and $5 \mathrm{~m}$ are not enough to cause DNA damage in zoospores of Laminaria saccharina during exposure for $16 \mathrm{~h}$, but are able to induce some impairment in germination capacity (ca 25\%). Exposure to natural irradiances for $16 \mathrm{~h}$ are not uncommon in spring-summer; therefore, dose-response data may be a realistic basis of the UV tolerance of zoospores as the low levels of incident irradiance and the relatively high vertical attenuation in this area make a direct effect of photon fluence rates of UVB unlikely.

Artificial weighted UVB dose close to $0.5 \mathrm{~kJ} \mathrm{~m} \mathrm{~m}^{-2}$ (DNA damage action spectrum) caused up to $60 \%$ photoinhibition of chlorophyll fluorescence in zoospores of Laminaria digitata. These UVB doses are in the range estimated using in situ quantum doses at 0 to $2 \mathrm{~m}$ depth, which strongly suggests that zoospore photosynthesis is reduced under natural solar radiation in Kongsfjorden, similar to reports for macrothalli of different species from this area (Bischof et al. 1998a, Hanelt 1998). The question of whether reductions in photosynthetic capacity and viability diminish recruitment rates remains unresolved. Nevertheless, unstable substrate and ice abrasion rather than a direct deleterious effect of UVB radiation might considerably limit zoospore attachment in shallow waters between 0 and $2 \mathrm{~m}$ depth in Kongsfjorden.

The deep-water Laminariales from southern Spain do not grow at depths $<10 \mathrm{~m}$ and members of the 

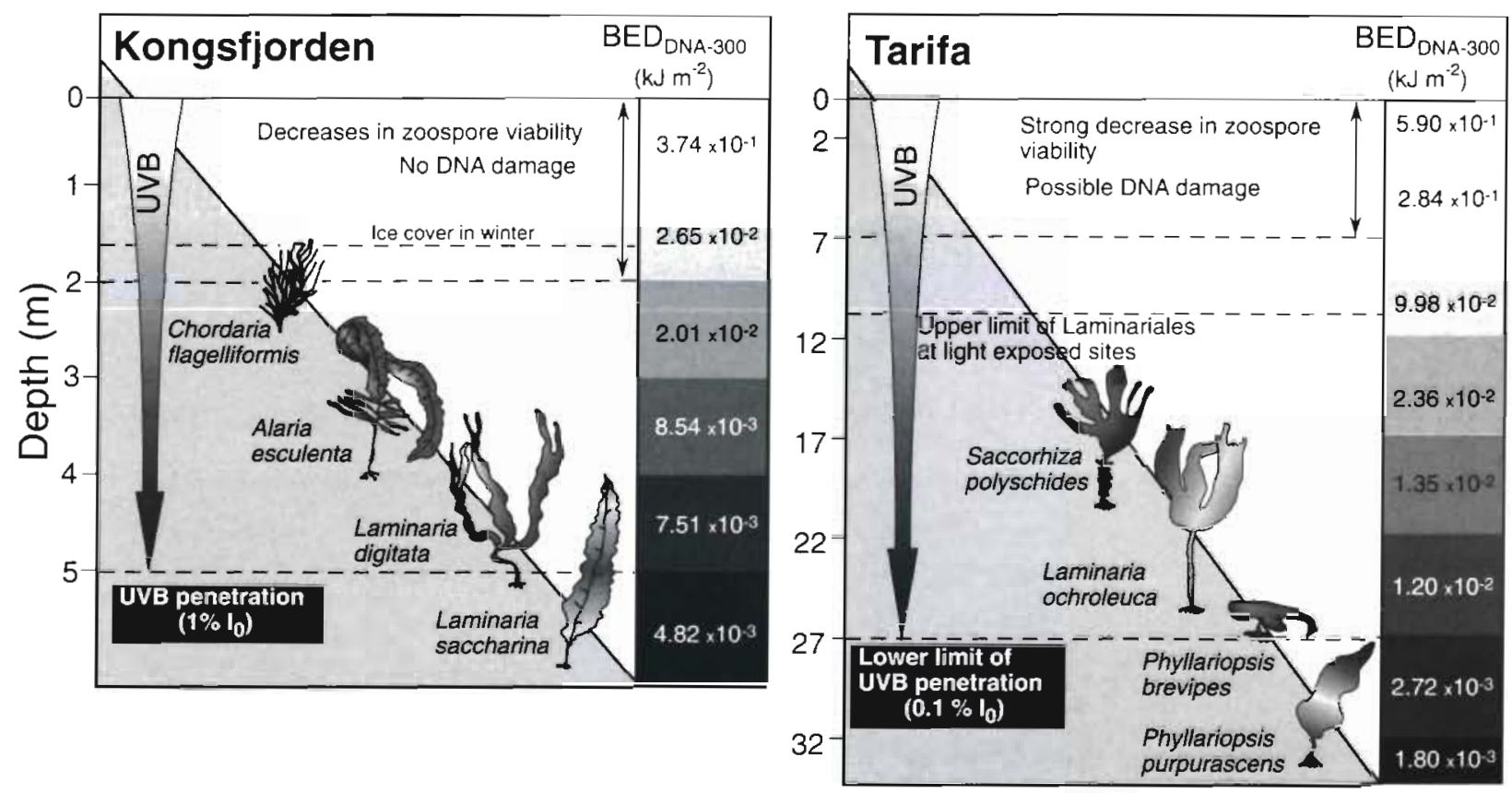

Fig. 7. Hypothesized scenarios relating prevailing vertical UVB conditions (weighted UV doses) and major biological and biooptical events to the macroalgal zonation in Kongsfjorden and Tarifa. Weighted UVB doses (DNA damage, Setlow 1974) were estimated by assuming constant photon fluence rates during $16 \mathrm{~h}$ exposure for Kongsfjorden and $8 \mathrm{~h}$ for Tarifa

genus Phyllariopsis are restricted to depths $>20 \mathrm{~m}$ (Flores-Moya 1997). Most individuals of these species grow at irradiances $<1 \%$ of surface irradiance (Drew et al. 1982, Flores-Moya 1997). However, the seasonal occurrence of juvenile individuals of Phyllariopsis sp. in shaded sites in the upper sublittoral (4 m), a phenomenon traditionally associated with local upwelling of deeper, colder waters (Rodríguez 1982, Flores-Moya 1997), supports the idea that light relations are important in governing depth zonation in these species (Flores-Moya et al. 1993). Our study revealed that the deep-water species Phyllariopsis purpurascens and $P$. brevipes show the highest mortalities rates after $4 \mathrm{~h}$ exposure to different UV conditions. Weighted UVB doses close to $0.5 \mathrm{~kJ} \mathrm{~m}^{-2}$ were found to cause $50 \%$ of spore mortality in this species, which would limit germination (and possibly attachment) of zoospores at depths above $7 \mathrm{~m}$, where BEDs $=0.3 \mathrm{~kJ} \mathrm{~m}^{-2}$ after a period of $8 \mathrm{~h}$ may occur. These levels may also be considered deleterious at the molecular level (DNA damage). Although optical characteristics of these waters allow UVB to penetrate down to depths of $25 \mathrm{~m}\left(D_{0} 1\right)$, no effects of UV-radiation between 10 and $32 \mathrm{~m}$ depth on germination rates could be demonstrated. Undoubtedly, the light conditions are subjected to strong variation and such scenarios extrapolated from instantaneous measurements cannot be used as the only elements to explain the complex phenomena involved in the zonation of these species, but may be seen as a preliminary identification of possible photobiological processes.

Acknowledgements. The authors thank the financial support of the Environment and Climate Program of the European Union through the project ENV4-CT96-0188, DG12-UV' Marine macrophytes. B. Vögele, H. Lippert, T. Sawall, A. Mascher, M. Kopp, E. Pérez and R. Conde are acknowledged for their assistance during diving, laboratory work and light data-collecting. Thanks go also to $\mathrm{H}$. Tüg and T. Hanken for cooperation during light profiling in the Arctic and to $\mathrm{M}$. Schoenwaelder for critically reading the manuscript. Part of this study was performed in $1997 / 1998$ on Spitsbergen at the Ny Ålesund International Research and Monitoring Facility. We thank the scientific and logistic staff at the Koldewey Station on Spitsbergen for the collaboration and hospitality during the study. This is publication No. 1696 of the Alfred Wegener Institute.

\section{LITERATURE CITED}

Amsler CD, Neushul M (1991) Photosynthetic physiology and chemical composition of zoospores of the kelps Macrocystis pyrifera, Nereocystis luetkeana, Laminaria farlowil, and Pterigophora californica (Phaeophyceae). J Phycol 27:26-34

Beggs CJ, Schneider-Ziebert U, Wellmann E (1986) UV-B radiation and adaptive mechanisms in plants. In: Worrest $\mathrm{RC}$, Caldwell MM (eds) Stratospheric ozone reductions, solar ultraviolet radiation and plant Life. NATO ASI Series G. Vol 8. Springer-Verlag, Berlin, p 235-250 
Bischof $\mathrm{K}$, Hanelt $\mathrm{D}$, Tüg $\mathrm{H}$, Karsten $\mathrm{U}$, Brouwer PEM, Wiencke C (1998a) Acclimation of brown algal photosynthesis to ultraviolet radiation in Arctic coastal waters (Spitsbergen, Norway). Polar Biol 20:388-395

Bischof $K$, Hanelt D, Wiencke C (1998b) UV-radiation can affect depth-zonation of Antarctic macroalgae. Mar Biol $131: 597-605$

Bornman JF, Teramura AH (1993) Effects of ultraviolet-B radiation on terrestrial plants. In: Young $A R$, Moan J, Björn LO, Nultsch W (eds) Environmental UV photobiology. Plenum Press, New York, p 427-471

Buma AGJ, Haneneb EJ, van Roza L, Veldhuis MJW, Gieskes WWC (1995) Monitoring ultraviolet B-induced DNA damage in individual diatom cells by immunofluorescence thymine dimer detection. J Phycol 31: $314-321$

Caldwell MM (1971) Solar ultraviolet radiation and the growth and development of higher plants, In: Giese AC (ed) Photophysiology. Academic Press, New York, p $131-177$

Charter AC, Neushul M, Coon D (1973) The effect of water motion on algal spore adhesion. Limnol Oceanogr 18: $884-896$

Cullen JJ, Lesser MP (1991) Inhibition of photosynthesis by ultraviolet radiation as a function of dose and dosage rate: results for a marine diatom. Mar Biol 111:183-190

Davidson AT, Marchant HJ (1994) The impact of ultraviolet radiation on Phaeocystis and selected species of Antarctic marine diatoms. Antarct Res Ser 62:187-205

Drew EA, Ireland JF, Muir C, Robertson WAA, Robinson JD (1982) Photosynthesis, respiration and other factors influencing the growth of Laminaria ochroleuca Pyl. below 50 meters in the Straits of Messina. PSZN I: Mar Ecol 4: $227-250$

Dring MJ, Makarov V, Schoschina E, Lorenz M, Lüning $K$ (1996a) Influence of ultraviolet-radiation on chlorophyll fluorescence and growth in different life-history stages of three species of Laminaria (Phaeophyta). Mar Biol 126: $183-191$

Dring MJ, Wagner A, Boeskov J, Lüning K (1996b) Sensitivity of intertidal and subtidal red algae to UVA and UVB radiation, as monitored by chlorophyll fluorescence measurements: influence of collection depth and season, and length of irradiation. Eur J Phycol 31:293-302

Ekelund NGA (1996) Effects of protein synthesis inhibitors on photoinhibition by UV-B $(280-320 \mathrm{~nm})$ radiation in the flagellate Euglena gracilis. Sci Mar 60(Suppl):95-100

Enriquez S, Agustí S, Duarte CM (1994) Light absorption by marine macrophytes. Oecologia 98:121-129

Figueroa FL, Blanco JM, Jiménez-Gómez P, Rodruíguez J (1997a) Effects of ultraviolet radiation on carbon fixation in Antarctic nanoflagellates. Photochem Photobiol 66: 185-189

Figueroa FL, Salles S, Aguilera J, Jiménez C, Mercado J, Viñegla B, Flores-Moya A, Altamirano M (1997b) Effects of solar radiation on photoinhibition and pigmentation in the red alga Porphyra leucosticta. Mar Ecol Prog Ser 151: $81-90$

Flores-Moya A (1997) Changes in reproductive effort, laminaarea index, and standing crop with depth in the deepwater alga Phyllariopsis purpurascens (Laminariales, Phaeophyta). Phycologia 36:32-37

Flores-Moya A, Fernández JA, Niell FX (1993) Reproductive phenology, growth and primary production of Phyllariopsis purpurascens (Phyllariaceae, Phaeophyta) from the Straits of Gibraltar. Eur J Phycol 28:223-230

Franklin LA, Forster RM (1997) The changing irradiance envi- ronment: consequences for marine macrophyte physiology, productivity and ecology. Eur J Phycol 32:207-232

Garcia-Pichel F (1996) The absorption of ultraviolet radiation by microalgae: simple optic and photobiological implications. Sci Mar 60(Suppl):73-79

Gieskes WWC, Buma AGJ (1997) UV damage to plant life in a photobiologically dynamic environment: the case of marine phytoplankton. Plant Ecol 128:16-25

Gómez I, Wiencke C (1996) Photosynthesis, dark respiration and pigment contents of gametophytes and sporophytes of the Antarctic brown alga Desmarestia menziesii. Bot Mar 39:149-157

Graham MH (1996) Effect of high irradiance on recruitment of the giant kelp Macrocystis (Phaeophyta) in shallow water. J Phycol 32:903-906

Häder DP, Figueroa FL (1997) Photoecophysiology of marine macroalgae. Photochem Photobiol 66:1-14

Häder DP, Häder M (1988) Inhibition of motility and phototaxis in the green flagellate, Euglena gracilis, by UV-B radiation. Arch Microbiol 150:20-25

Häder DP, Häder M (1989) Effects of solar UV-B irradiation on photomovement and motility in photosynthetic and colorless flagellates. Environ Exp Bot 29:273-282

Häder DP, Lebert M, Flores-Moya A, Jiménez C, Mercado J, Salles S, Aguilera J, Figueroa FL (1997) Effects of solar radiation on the photosynthetic activity of the red alga Corallina elongata Ellis et Soland. J Photochem Photobiol B Biol 37:196-202

Halldal P (1964) Ultraviolet action spectra of photosynthesis inhibition in a green and a red alga. Physiol Plant 17: $414-421$

Hanelt D (1998) Capability of dynamic photoinhibition in Arctic macroalgae is related to their depth distribution. Mar Biol 131:361-369

Hanelt D, Wiencke C, Karsten U, Nultsch W (1997a) Photoinhibition and recovery after high light stress in different developmental and life-history stages of Laminaria saccharina (Phaeophyta). J Phycol 33:387-395

Hanelt D, Wiencke C, Nultsch W (1997b) Influence of UVradiation on the photosynthesis of Arctic macroalgae in the field. J Photochem Photochem B Bial 38:40-47

Helbling EW, Villafañe $V$, Holm-Hansen O (1994) Effects of ultraviolet radiation on Antarctic marine phytoplankton photosynthesis with particular attention to the influence of mixing. Antarctic Res Ser 62:207-227

Henry EC, Cole KM (1982) Ultrastructure of swarmers in the Laminariales (Phaeophyceae). I. Zoospores. J Phycol 18 $550-569$

Holm-Hansen O, Lubin D, Helbling EW (1993) Ultraviolet radiation and its effects on organisms in aquatic environments In: Young AR, Moan $\mathbf{J}$, Björn LO, Nultsch W (eds) Environmental UV photobiology. Plenum Press, New York, p 379-425

Ito $H$, Kudoh $S$ (1997) Characteristics of water in Kongsfjorden, Svalbard. Proc NIPR Symp Polar Meterol Glaciol 11: 211-232

Jiménez C, Figueroa FL, Salles $S$, Aguilera J, Mercado J, Viñegla B, Flores-Moya A, Lebert M, Häder DP (1998) Effects of solar radiation on photosynthesis and photoinhibition in red macrophytes from an intertidal system of southern Spain. Bot Mar 41:329-338

Kain JM (1964) Aspects of the biology of Laminaria hyperborea. III. Survival and growth of gametophytes. J Mar Biol Assoc UK 44:415-433

Karentz D, Cleaver JE, Mitchell DL (1991) Cell survival characteristics and molecular responses of Antarctic phytoplankton to ultraviolet-B radiation. J Phycol 27:326-341 
Larkum AWD. Wood WF (1993) The effect of UV-B radiation on photosynthesis and respiration of phytoplankton, benthic macroalgae and seagrasses. Photosynth Res 36:17-23

Lee RE (1989) Phycology, 2nd edn. Cambridge University Press, Cambridge

Lüning K (1979) Growth strategies of three Laminaria species (Phaeophyceae) inhabiting different depth zones in the sublittoral region of Helgoland (North Sea). Mar Ecol Prog Ser 1:195-207

Lüning K (1980) Critical levels of light and temperature regulating the gametogenesis of three Laminaria species (Phaeophyceae). J Phycol 16:1-15

Lüning K, Dring MJ (1979) Continuous underwater light measurements near Helgoland (North Sea) and its significance for characteristic light limits in the sublittoral region. Helgol Wiss Meeresunters 32:403-424

Maegawa M, Kunieda M, Kida W (1993) The influence of ultraviolet radiation on the photosynthetic activity of several red algae from different depths. Jpn J Phycol (Sôrui) $41: 207-214$

Makarov VN (1992) The behaviour of Laminaria saccharina (Phaeophyta) zoospores. Technical Report Academia of Science of Russia

Mitchell DL, Karentz D (1993) The induction and repair of DNA photodamage in the environment. In: Young AR, Moan $J_{1}$ Björn LO, Nultsch $W$ (eds) Environmental UV photobiology. Plenum Press, New York p 345-377

Molina X, Montecino V (1996) Acclimation to UV irradiance in Gracilaria chilensis Bird, McLachlan et Oliveira (Gigartinales, Rhodophyta). Hydrobiologia 326/327:415-420

Munakata N (1995) Continual increase in biologically effective dose of solar UV-radiation determined by spore dosimetry from 1980 to 1993 in Tokyo. J Photochem Photobiol B Biol 31:63-68

Nilawati J, Greenberg BM, Smith REH (1997) Influence of ultraviolet radiation on growth and photosynthesis of two cold ocean diatoms. J Phycol 33:215-224

Pérez-Rodríguez E, Gómez I, Karsten U, Figueroa FL (1998) Effects of UV-radiation on photosynthesis and excretion of UV-absorbing compounds of Dasycladus vermicularis (Dasycladales, Chlorophyta) from southern Spain. Phycologia 37:379-387

Quaite FE, Sutherland BM, Sutherland JC (1992) Action spectrum for DNA damage in alfalfa lowers predicted impact of ozone depletion. Nature 358:576-578

Quintern LE, Furusawa Y, Fukutsu K, Holtschmidt H (1997) Characterization and application of UV detector sporefilms: the responsivity curve of a new detector system provides good similarity to the action spectrum for UVinduced erythema in human skin. $J$ Photochem Photobiol B Biol 37:158-166

Editorial responsibility: Otto Kinne (Editor),

Oldendorf/Luhe, Germany
Reed DC (1990) The effects of variable settlement and early competition on patterns of kelps recruitments. Ecology 71 : $776-787$

Rodríguez J (ed) (1982) Oceanografía del mar Mediterráneo. Pirámide, Madrid

Roza L, van der Wulp KJ, Macfarlan SJ, Lohman PHM, Baan RA (1988) Detection of cyclobutane thymine dimers in DNA of human cells with monoclonal antibodies raised against a thymine dimer-containing tetranucleotide. Photochem Photobiol 48:627-633

Rundel RD (1983) Action spectra and estimation of biologically effective UV-radiation. Physiol Plant 58:360-366

Sagert S, Forster RM, Feuerpfeil P, Schubert H (1997) Daily course of photosynthesis and photoinhibition in Chondrus crispus (Rhodophyta) from different shore levels. Eur J Phycol 32:363-371

Schreiber U, Schliwa U, Bilger W (1986) Continuous recording of photochemical and non-photochemical chlorophyll fluorescence quenching with a new type of modulation fluorometer. Photosyn Res 10:51-62

Setlow RB (1974) The wavelengths in sunlight effective in producing skin cancer: a theoretical analysis. Proc Nat Acad Sci USA 71:3363-3366

Small GD, Greimann CS (1977) Repair of pyrimidine dimers in ultraviolet-irradiated Chlamydomonas. Photochem Photobiol 25:183-187

Smith RC, Baker KS, Holm-Hansen O, Olson RS (1980) Photoinhibition of photosynthesis in natural waters. Photochem Photobiol 31:585-592

Sokal RR, Rohlf FJ (1995) Biometry, 3rd edn. WH Freeman, New York

Start RC, Zeikus JA (1987) UTEX - a culture collection of algae at the University of Texas at Austin. J Phycol 23(Suppl):1-47

Svendsen P (1959) The algal vegetation of Spitsbergen: a survey of the marine algal flora of the outer part of Isfjorden. Norsk Polarinst Report No. 116

Tyrrell RM (1995) Biological dosimetry and action spectra. $J$ Photochem Photobiol B Biol 31:35-41

Vink AA, Bergen-Henegouwen JB, Nikaido O, Baan RB, Roza $L$ (1994) Removal of UV induced DNA lesions in mouse epidermis soon after irradiation. J Photochem Photobiol B Biol 24:25-31

Wängberg SA, Selmer JS, Eklund NGA, Gustavson K (1996) UV-B effects on Nordic marine ecosystem: a literature review. Nordic Council of Ministers, Copenhagen

Yabe K, Makino M, Susuki M (1997) Growth-inhibition on gametophytes of Laminaria religiosa induced by UV-B radiation. Fish Sci 63:668-670

Yakovleva IM. Dring M. Titlyanov EA (1998) Tolerance of North Sea algae to UV and visible radiation. Russ J Plant Physiol 45:45-54

Submitted: August 20, 1999; Accepted: December 1, 1999 Proofs received from author(s): April 13, 2000 